\title{
Preparedness, Crisis Management and Policy Change: The Euro Area at the Critical Juncture of 2008-2013
}

\author{
Benjamin Braun
}

\section{Research Highlights and Abstract}

- This article contributes to the literature on ideational and institutional change at critical junctures more generally, and in the context of economic crises in particular.

- In the context of explosive economic crises critical junctures should be conceptualised as consisting of two distinct phases-a phase of emergency crisis management and a subsequent phase of purposeful institution building.

- The analytical significance of the crisis management phase lies in its tendency to create path dependencies for subsequent ideational entrepreneurs and institution building efforts.

- Crisis management is always 'bricolage'. However, in order to understand why certain tools are 'at hand' during a crisis, one needs to take into account the variable of crisis preparedness. Contingency planning for non-normal times is a constitutive aspect of any economic policy paradigm.

- The empirical analysis shows that the euro area's lack of preparedness caused the ECB to assume a dominant position during the emergency phase of the crisis. This windfall gain in power for the ECB has already begun to shape the future institutional architecture of the EMU.

Focusing on the experience of the euro area in general, and the ECB in particular, this article argues that in the context of explosive financial crises a phase of emergency crisis management precedes the phase of purposeful institution building. Importantly for our understanding of policy change, crisis management measures create their own path dependencies. However, albeit often improvised, crisis management decisions are not entirely contingent. The article therefore introduces the notion of preparedness, which measures the extent to which the pre-crisis policy paradigm was prepared for the joint occurrence of, in this case, a systemic banking crisis and a sovereign debt crisis. The analysis shows that the Euro area's lack of preparedness caused the ECB to assume a dominant position in the euro area during the emergency phase of the crisis. This windfall gain in power for the ECB has already begun to shape the future institutional architecture of the EMU.

Keywords: policy paradigm; critical junctures; European Central Bank; crisis management

\section{Introduction}

In recent years, the literatures on critical junctures in general (Pierson 2004; Capoccia and Kelemen 2007), and on political change in the context of economic 
crises in particular (Blyth 2002, 35; Chwieroth 2010, 497; Helleiner 2010, 620), have put increasing emphasis on the temporal dynamics of such processes of change. The present article shares this concern, but argues that the sequencing in the literature is incomplete in that it understates the importance of the 'emergency' phase of an economic crisis, which occurs before actors begin to intentionally devise new institutions. Although Blyth $(2002,35)$, for instance, distinguishes 'between the reduction of uncertainty by ideas and the subsequent creation of institutions', he does not integrate the phase of emergency crisis management into his theory of 'great transformations'.

The argument that emergency crisis management matters is of particular relevance in the case of what Baker (forthcoming) has aptly called 'explosive crises'. While Baker talks about varieties of economic crisis more generally, financial crises are by definition explosive. The recent upheaval in the euro area is a prime example. Most observers agree that the emergency phase of the crisis in the euro area lasted from the failure of Lehman Brothers in September 2008 to the announcement of the ECB's Outright Monetary Transactions (OMT) programme in August 2012, which almost immediately stabilised interest rates in sovereign debt markets (Financial Times, 13 December 2013). During this emergency phase, policy decisions were not necessarily guided by either the old or a potential future policy paradigm. By acting the way they did, crisis managers, without necessarily intending to do so, set several precedents that have left their imprint on the ideational and institutional landscape. In other words, emergency crisis management actions create new path dependencies, which purposeful institutional entrepreneurs may later find it difficult to escape from. By neglecting emergency crisis management, the critical juncture literature tends to have an overly strategic or voluntaristic understanding of institutional change.

However, the argument that the actions of crisis managers affect the likelihood as well as the direction of ideational and institutional change raises the question of why crisis managers act the way they do. This calls for an extension of the analysis of crisis management into the past in order to assess the degree to which the pre-crisis policy paradigm was prepared-both ideationally and institutionally-for the crisis that materialised. Such preparedness, it is argued, is a crucial variable for paradigm resilience. An economic policy paradigm is not necessarily undermined by economic instability. If it accounts for the occurrence of certain events and offers guidance on how to deal with them, it is less likely to be displaced by their actual occurrence than a policy paradigm that lacks such preparedness. It follows that crisis management policies should not be compared to pre-crisis policy routines for normal times, but to pre-crisis contingency planning for non-normal times. Again, the case of the role of the ECB is instructive in this respect, since central bankers traditionally draw a sharp line between normal times and periods of financial crisis.

The structure of the article is as follows. Beginning with a brief review of the literature on critical junctures and policy paradigms, the second section then goes on to elaborate the theoretical argument about the importance of the phase of emergency crisis management for the process of ideational and institutional change. The third section reviews the conceptions of the normal and the non-normal, as well as the contingency plans that were embedded in the pre-crisis macroeconomic 
policy paradigm of the euro area with regard to both banking crises and sovereign debt crises. The fourth section then compares this to actual crisis management from 2008 to 2012, thereby distinguishing between a pure banking crisis in the first phase, and a second phase during which the banking crisis was reinforced by a sovereign debt crisis. The conclusion sums up the results of the empirical analysis and offers a tentative interpretation of recent developments in monetary and financial stability policy on the basis of the theoretical perspective developed in this article.

\section{Policy Paradigms, Preparedness, and Crisis Management}

The key insight of historical institutionalism with regard to critical junctures is that "junctures are "critical" because they place institutional arrangements on paths or trajectories, which are then very difficult to alter' (Pierson 2004, 135). In an important recent contribution, Capoccia and Kelemen define a critical juncture as 'a situation in which the structural ... influences on political action are significantly relaxed for a relatively short period', whereby 'relatively short' means 'brief relative to the duration of the path-dependent process that it initiates' (Capoccia and Kelemen 2007, 343, 350). ${ }^{1}$

The notion of critical junctures is not unique to historical institutionalism. Namely, the literature on ideational paradigm shifts in the context of economic crises has always used a critical junctures approach-if only, in many cases, implicitly. ${ }^{2}$ In his seminal article, Hall $(1993,279)$ defined a policy paradigm as an interpretive framework' that is shared widely among policy-makers and that specifies not only the goals and instruments of policy, 'but also the very nature of the problems they are meant to be addressing'. Drawing on Kuhn (1962), Hall argued that policy paradigms could be destabilised by 'developments that are not fully comprehensible, even as puzzles, within the terms of the paradigm' (Hall 1993, 280). However, as long as change is restricted to the levels of instruments or techniques-what Hall calls first and second order change-'normal policymaking' prevails. It is only when the underlying goals that guide policy are transformed that one can speak of third-order change, i.e., a paradigm shift (Hall 1993, 279). Hall's argument that economic crises provide entry points for new ideas has subsequently been elaborated by Blyth, who argued that in situations of heightened uncertainty actors are not only uncertain about how to advance their interests, but are actually uncertain of what their interests are in the first place (Blyth 2002, 32). By providing a new interpretive framework that enables actors to make sense of what is going on, ideas reduce perceived uncertainty and thus make (collective) action possible.

In the face of 'The Strange Non-Death of Neoliberalism' (Crouch 2011), the notion of a strong correlation between economic crises and policy paradigm shifts has recently been amended and challenged in various ways. For instance, Colin Hay (2011) argues that economic crises do not necessarily come complete with a new set of economic ideas to replace old ones. The absence of a paradigm shift in the aftermath of the recent global financial crisis may therefore be explained simply by the absence of a coherent set of novel ideas. Other contributions challenge purely ideational explanations of ideational change, pointing to the power resources of 
groups of ideational entrepreneurs (Mandelkern and Shalev 2010) or their composition and credibility with external actors (Chwieroth 2010). In a similar vein, Blyth (2013) reiterates Hall's point that third-order change is always the outcome of a struggle about the meaning of anomalies, and therefore has more to do with authority than with purely ideational factors.

The present article shares the scepticism displayed in these contributions towards a mechanistic understanding of ideational and institutional change in times of economic crisis. However, it argues that in order to do justice to the temporal dynamics of such change scholars need to account for what happens during the emergency phase of explosive crises.

\subsection{Explosions, Emergencies, and the Temporality of Change}

The present article understands the period since 2008 as a critical juncture for the institutional architecture of the European Monetary and Economic Union (EMU) in the three policy areas of monetary, fiscal, and financial stability policy. However, it argues that in the present context only a modified concept of 'critical juncture' can be analytically useful. To see why, it is important to point out that the literature on economic policy paradigm shifts has drawn heavily on the stagflation crisis of the 1970s and the subsequent shift towards monetarism (Oliver and Pemberton 2004). This episode is commonly regarded as a textbook case of a critical juncture. However, there is little doubt that the recent global financial crisis in general, and the euro area crisis in particular, are different from this earlier episode, which was essentially a 'slow-burning' crisis of the real economy. In terms of crisis management, the current crisis of the financial economy is special due to its explosive character. Note that this explosiveness is not reduced by the fact that the emergency phase of the crisis lasted almost four years, from September 2008 (failure of Lehman Brothers) to August 2012 (announcement of OMT by the ECB). ${ }^{3}$ Rather than overall duration, the distinguishing characteristic of an explosive crisis is the (perceived) degree of urgency under which policymakers act. In the case of the euro crisis, this urgency resulted from uncertainty about the solvency of systemically important banks and governments. There was a pervasive feeling that a single event or policy error could bring down the entire financial system of the euro area. Certainly, policy-makers did not act under the same pressure during the stagflation crisis of the 1970s. The emergency phase thus lasted as long as sudden insolvencies of systemically important banks or governments were considered possible events. These fears were contained only when the ECB announced OMT. ${ }^{4}$

It is important to note that saying that the announcement of OMT in August 2012 marks a break in the dynamic of the euro area crisis does not imply that it also marks the end of the critical juncture that the crisis has created for the institutional architecture of the EMU. Instead, the following analysis is based on the notion that this particular critical juncture consists of two distinct phases-a phase of emergency crisis management (2008-2012) and a subsequent phase of purposeful institution building (since 2012). This distinction is of immediate analytical relevance in the sense that the imperatives of emergency crisis management prevent political actors from engaging in the 'strategic social constructions' that figure so 
prominently in the literature on ideational change (Finnemore and Sikkink 1998, 888; quoted in Widmaier et al. 2007, 748). Thus, despite the hyperactive pace of decision making during the first four years of this critical juncture, the euro area entered the phase of grand-design institutional reform only late in $2012 .^{5}$ Consequently, emphasising the causal significance of improvised crisis management decisions means avoiding the voluntaristic bias that is built into the critical juncture literature. Thus, Mahoney $(2001,7)$ defines critical junctures as 'moments of relative structural indeterminism when wilful actors shape outcomes in a more voluntaristic fashion than normal circumstances permit'. ${ }^{6}$ While it is true that the 'structural indeterminism' of critical junctures increases the likelihood of individual or collective agency to make a difference, the implicit supposition of purposefulness is problematic. This is because during the emergency phase of explosive crises policy-makers take actions that, in spite of their ad hoc nature, create their own path-dependencies before the intentional process of institution building has actually begun.

Thus, the distinction between the two phases of the current critical juncture is analytically important because both the likelihood and the direction of a potential paradigm shift are influenced by the decisions that are taken and implemented during the emergency phase. While not necessarily informed by any paradigm, the decisions taken during the emergency phase of a crisis do necessarily affect the further evolution of ideas and institutions. During the recent crisis, for instance, the combination of the Lehman shock with the absence of a European bank resolution mechanism forced the ECB to be an extremely generous lender of last resort to the banking sector, thus saving a potentially large number of institutions that would otherwise have failed (or at least shrunk). As a consequence, as the phase of purposeful institutional reform began in the second half of 2012, politicians and regulators faced a banking sector whose power and profitability were not far below pre-crisis levels. In other words, although likely to be ad hoc, decisions taken during the emergency phase constitute the seeds of future path-dependent developments and thus have consequences that reach far into the future.

That said, however, the next step must be to ask why crisis managers act the way the do. In this context, an interesting conceptualisation of agency in policymaking has recently been presented by Carstensen (2011), who opposes the individual agency of the 'bricoleur' to the figure of 'paradigm man'. While the latter is supposed to internalise the ideas associated with a policy paradigm, the former implies a more open conception of agency, according to which policy-makers 'are able to reflect critically on the ideas they use' and to 'combine them indiscriminately of which paradigm they belong to' (ibid., 164). Carstensen quotes Levi-Strauss' definition, whereby the bricoleur uses 'whatever is at hand' at any present moment (ibid., 154) and rightly points out that 'bricolage also occurs in crises' (ibid., 161). However, while undoubtedly correct, this leaves unanswered the question of which tools are 'at hand' at the moment of crisis, and how they got there (or not). This question suggests that only if crisis management is put in historical perspective can a key variable of paradigm resilience be taken into account-the crisis preparedness of the pre-crisis policy paradigm. 


\subsection{Preparedness and Resilience: The Normal, the Non-normal and the Abnormal}

Depending on which contingencies it envisages as possible, and on how it anchors such contingency planning in the institutional order, a policy paradigm can be more or less prepared for certain crisis scenarios. Other things being equal, a higher degree of preparedness reduces the likelihood of a breakdown of the paradigm during a crisis, thus increasing paradigm resilience. Note, however, that the reverse is not necessarily true, as contingent events during the emergency phase of a crisis play an important role. In the case of the twin crisis in the euro area, a lack of preparedness has led to a situation in which the ECB was the only actor legally and financially capable of making decisive interventions. This strengthened its position vis-à-vis other institutions in the governance architecture of the euro area, thus increasing its power to influence the evolution of the policy paradigm. For this reason, the impact of the diagnosed lack of preparedness on paradigm resilience is not necessarily negative-the disorder that resulted from the EMU's unpreparedness has strengthened the ECB's capacity for paradigm maintenance in certain areas of vital interest to itself, such as monetary policy (this point is taken up again in the conclusion). Briefly, the relationship between preparedness and resilience is non-linear.

This important qualification notwithstanding, the way in which a paradigm draws the boundaries between the normal, the non-normal and the abnormal prior to a critical juncture has important ramifications for how the processes of ideational and institutional change unfolds during a critical juncture. The relation between a policy paradigm and what is considered to be a normal state of the world is co-constitutive-necessarily, a policy paradigm defines a certain range of states of the world as normal, while at the same time the (perceived) existence of such normality is the precondition for the theoretical validity as well as the practical applicability of the policy paradigm. To the extent that certain non-normal events are deemed possible states of the world, a policy paradigm also makes provisions for the occurrence of such events. However, a policy paradigm is not only defined by what it has to say about appropriate policies for normal and non-normal times, but also by what remains beyond the scope of the paradigm. Such unaccounted-for events and developments can be thought of with Luhmann as 'blind spots', in Rumsfeldian terms as 'unknown unknowns', as 'fat tail events' or 'black swans' as Mandelbrot and Taleb would have it, or simply as abnormal scenarios-as opposed to accounted-for non-normal scenarios.

There is a widespread consensus that from the perspective of the pre-crisis policy paradigm the failures of institutions such as Bear Stearns, Lehman Brothers and AIG were abnormal events, the joint occurrence of which was simply inconceivable within the risk models of the pre-crisis era, which were based on rational expectations and the notion that markets were efficient. Saying that the crisis was not predicted, however, does not imply that the policy paradigm had nothing to say about the handling of a systemic financial crisis. Not knowing if or when $\mathrm{X}$ happens is not the same as being unaware that $\mathrm{X}$ could possibly happen. This important nuance is not sufficiently discussed in the literature on risk, uncertainty, and 
ambiguity (Blyth 2002; Best 2005, 2008 and 2012; Katzenstein and Nelson 2013). Of course, the future is always uncertain-'we simply do not know' what is going to happen tomorrow (Keynes 1937, 214). At the same time, however, the regular occurrence of financial crises has been a pervasive feature ever since the inception of capitalism, and certainly during the decades that preceded the most recent episode (Kindleberger 1978; Reinhart and Rogoff 2009). In this sense, the financial crisis of 2008-2012 is very different from the stagflation crisis of the 1970s. While the phenomenon of stagflation was novel and could not be explained on the basis of past experience and established economic theories, the historical record shows that the recent twin crisis was quite conventional-a classic asset price bubble whose bursting caused a banking crisis, which in Europe developed into an equally classic sovereign debt crisis (Reinhart and Rogoff 2009). Although the sheer scale of it was indeed unprecedented, the generic phenomenon was hardly new. Consequently, even if the pre-crisis policy paradigm did not predict the crisis, it was not entirely unprepared.

The resilience of a policy paradigm in the face of crisis is at least partly a function of crisis preparedness, and thus of contingency planning. ${ }^{7}$ Contingency planning is about imagining possible futures at times when the present gives little indication of what the future might look like. Anomalies that are anticipated and accommodated through contingency planning cease to be anomalies and are reduced to nonnormal events, which are less likely to invalidate the existing policy paradigm. Central banking is a particularly pertinent case in this context. It is widely recognized that the role of the central bank in normal times is very different from its role in financial crises. ${ }^{8}$ Traditionally, price stability is the central bank's top priority in normal times, but financial stability becomes the overriding goal in non-normal times. Hence the shift in instruments, techniques, and potentially even goals that could be observed during the recent financial crisis in the euro area does not necessarily indicate a paradigm shift. If one wishes to assess the degree to which recent $\mathrm{ECB}$ interventions are at odds with the old paradigm, the reference point cannot be the Bank's pre-crisis routine operations, but pre-crisis notions about appropriate policies in the event of a crisis. In the following, preparedness is therefore measured through a comparison of pre-crisis contingency planning and in-crisis contingency acting, which serves to identify the 'unknown unknowns' of the pre-crisis policy paradigm.

\section{Contingency Planning before the Crisis}

This section assesses the extent to which the EMU was ideationally and institutionally prepared for the two (closely interrelated) financial crises that hit the euro area in 2008 and in 2010. Two preliminary remarks are in place. First, the focus of this section is not primarily on the policy paradigm for normal times, but on those elements of the paradigm that related to non-normal times. Second, the scope of the crisis makes it necessary to take into account all three dimensions of macroeconomic governance-not only monetary policy, but also financial stability and fiscal policy. That said, the two subsections deal with contingency planning for a banking crisis, and for a sovereign debt crisis, respectively. In order to assess the degree of preparedness of the pre-crisis paradigm, each of these subsections 
addresses two questions. Firstly, did the pre-crisis policy paradigm seriously consider the possibility of a systemic banking crisis/a sovereign debt crisis? Secondly, did the pre-crisis paradigm envision concrete contingency measures, and did institutional structures exist to implement those measures in a crisis scenario?

\subsection{Contingency Planning for a Banking Crisis}

Did euro area policy-makers attach a positive probability to a systemic banking crisis of the kind that unfolded after the failure of Lehman Brothers? The answer to this question is ambiguous. On the one hand, academics and policy-makers have always been aware of the theoretical possibility of a systemic financial crisis. On the other hand, this awareness was embedded in a framework that, at a theoretical level, left very little room for financial instability of any kind. The two fundamental pillars of the monetary policy paradigm of the euro area were the efficient market hypothesis and the rational expectations hypothesis. Together, they formed the theoretical underpinning of what some have called the 'Jackson Hole Consensus' (Issing 2009; Bean et al. 2010, 3), after the venue of the annual retreat of the global central banking elite. According to this consensus, central banks should neither target asset prices nor prick asset price bubbles. ${ }^{9}$ Instead, they should limit themselves to 'mopping up after' (the burst of a bubble), mainly by providing emergency liquidity, instead of 'pricking' the bubble at an earlier stage (Bernanke and Gertler 2001; Greenspan 2002). Thus, while it absolved the central bank from responsibility for the build-up of financial bubbles, the Jackson Hole Consensus relied all the more strongly on the central bank to fulfil its lender of last resort (henceforth 'LOLR') role. In other words, even though the problem was largely assumed away in state-of-the-art macroeconomic models (Clarida 2012, 125), central bankers were aware of the practical relevance of financial instability.

This leads to the second question about the substantial content of contingency planning for the case of a financial crisis following the burst of a bubble. Here, the ECB differed significantly from its peers in other countries (as well as from many of its national predecessors). In a very foresighted 1992 paper, David Folkerts-Landau and Peter Garber argued that with continuing Europe-wide integration of highly liquid securitized money markets there would be a need for a central bank with explicit responsibility for financial stability, that is, with a mandate to supervise the banking sector and to act as LOLR in case of a liquidity crisis. The authors noted that at the point of writing the draft statute of the ECB subscribed to what they called a 'narrow' concept of central banking with an exclusive focus on price stability, as opposed to a 'broad' concept that includes financial stability objectives (Folkerts-Landau and Garber 1992, 31).

As it turned out, the final statute still lacked explicit financial stability objectives (Buiter 1999, 201), yet the securitisation of money markets continued regardless. By the time the ECB began its operations, there were two competing views regarding the fitness of the institutional infrastructure of the EMU for the financial stability challenges that came with the common currency. Stating that he knew 'of no central bank law within which the lender-of-last-resort function is explicitly defined', the ECB economist Tommaso Padoa-Schioppa $(1999,306)$ argued that "maintaining "constructive ambiguity" in these matters may help to reduce the 
moral hazard associated with a safety net'. In the same vein, Willem Buiter observed that despite the lack of an explicit LOLR mandate, there were no provisions in the EMU treaties that explicitly ruled out the possibility of the ECB acting as LOLR to the banking system (Buiter 1999, 199). Sceptics, on the other hand, while not doubting that the ECB together with national central banks would act as LOLR, questioned its ability to do so effectively, mainly because it lacked informational resources. For instance, the IMF warned that the ECB will be at the centre of European financial markets without the tools necessary for independently assessing creditworthiness of counterparties or the tools to provide direct support to solvent but illiquid institutions' (IMF 1998, 110). The report considered this situation unlikely to be sustainable and predicted that 'the ECB may soon be forced to assume a leading and coordinating role in crisis management and banking supervision' (ibid.). Others described the situation as one of 'destructive ambiguity', and predicted that a more explicit LOLR mandate for the ECB is inevitable and 'will evolve through the experience of crises and find its ways to fill the ambiguities of the Treaty' (Aglietta 1999, 25-27, 6). ${ }^{10}$ So far, both the emergency and the postemergency experiences suggest that these were highly accurate predictions.

The uncertainties about the LOLR role of the ECB notwithstanding, the so-called Bagehot rule, which had always been in the crisis-toolkit of central banks, provided unambiguous guidelines regarding the way in which the LOLR function should be executed. First formulated by Walter Bagehot (1873), the rule states that in a crisis scenario the central bank should lend freely, against good collateral, and at a high interest rate. These principles attempt to reconcile the conflicting goals of averting failure and financial contagion, minimising the risk of moral hazard, and protecting the central bank from incurring losses in its LOLR operations. Another, related view that had achieved common sense status among monetary policy-makers was Milton Friedman and Anna Schwartz's (1963) point that the Great Depression was caused by a contraction of the money supply, and that the Fed was therefore to blame. ${ }^{11}$ Not least due to research by Ben Bernanke (2000), the idea that it was imperative for the central bank in the event of a systemic banking crisis to provide ample liquidity through open market operations was firmly entrenched in the mind-set of monetary policy makers on both sides of the Atlantic. ${ }^{12}$ Thus, as far as the LOLR function was concerned, the pre-crisis paradigm was prepared for a systemic financial crisis, even in the absence of a formal ECB mandate to safeguard financial stability. It was this preparedness that prompted central bankers in the euro area and other financial centres to intervene decisively to shore up their respective banking sectors. Helping to avoid a meltdown of the financial system, this decisiveness arguably contributed to the observable resilience of the pre-crisis policy paradigm.

However, beyond the LOLR function, the role of the central bank in a banking crisis is also influenced by other factors, most notably the framework for bank resolution. This is because the extent of LOLR support for banks in large measure depends on the damage that the failure of a systemically important financial institution (SIFI) is expected to cause. Although the problems related to the resolution and liquidation of cross-border financial institutions were recognized early on, both the EU and its member states lacked the formal means to deal with distressed financial groups operating through multiple, separate legal entities (BCBS 2010, 3-4). At the 
national level, the design of resolution regimes varied widely. Variations concerned the actors involved (supervisors, central banks, finance ministries, courts, deposit guarantee schemes), their legal competencies, and the legal thresholds that would trigger insolvency proceedings (Cihak and Nier 2009, 9-10). At the EU level, binding ex ante commitments regarding bank resolution were all but non-existent. There were no agreements about burden sharing, and there was certainly no EU bank resolution regime (Pisani-Ferry and Sapir 2010). This left the euro area entirely exposed to the too-big-to-fail problem. Thus, in contrast to the LOLR function, which deals with liquidity issues, bank resolution, which is about insolvency, remained entirely beyond the scope of the pre-crisis policy paradigm. Since, as a consequence, large banks could not be allowed to fail, the ECB was forced to interpret its LOLR function very aggressively, during both the banking and the sovereign debt phase of the crisis. This crisis experience is the main driving force behind the most wide-reaching reform projects of the post-emergency phase, which include the Single Supervisory Mechanism, a Single Resolution Mechanism, and plans to introduce some sort of Glass-Steagall legislation to safeguard the commercial banking system from riskier investment banking activities.

\subsection{Contingency Planning for a Sovereign Debt Crisis}

Did the pre-crisis policy paradigm consider the actual default of a euro area member state a possible scenario? The central economic idea behind the common currency, as perceived at the time, was to stabilise and deepen European economic integration through the elimination of exchange rate risk (Eichengreen 1993). The price that member states had to pay for their membership in the euro area was the loss of their monetary sovereignty, as the task of monetary policy was centralised under the auspices of the newly established ECB. Regarding fiscal policy, the optimum currency area literature suggested that centralisation was the first best solution. ${ }^{13}$ As this was at no point a realistic scenario, a second best solution was adopted-the restriction of national fiscal sovereignty through the Stability and Growth Pact (SGP), which capped the annual budget deficit and the national public debt at 3 per cent and 60 per cent of GDP, respectively. The second pillar of the fiscal order of the EMU is constituted by the prohibition of debt monetisation through the ECB and the no-bail-out clause, which were enshrined in articles 123 and 125 of the Treaty on the Functioning of the European Union (TFEU). ${ }^{14}$ For the present argument, the most important implication of Art. 123 and 125 is that membership in the euro area does not protect states from the possibility of sovereign default.

However, prior to the euro area crisis, sovereign default was widely regarded as a problem of developing and emerging economies only. An IMF paper in 2008 found that the two decades between 1921 and 1940 were the last period in which default episodes could be observed for Western European countries (Borensztein and Panizza 2008, 6). Nevertheless, in the early 1990s, economists emphasised that euro area members would lose the option to monetise their national debt in order to avoid default. Although this cost was partially compensated by the elimination of exchange rate risk, economists predicted a net increase in default risk and therefore a higher risk premium on the bonds of some euro area members (Eichengreen et al. 1990, 164-165). However, this prediction turned out to be wrong, as the visual 
Figure 1: Total Government Debt, Percentage of GDP, 1999-2012

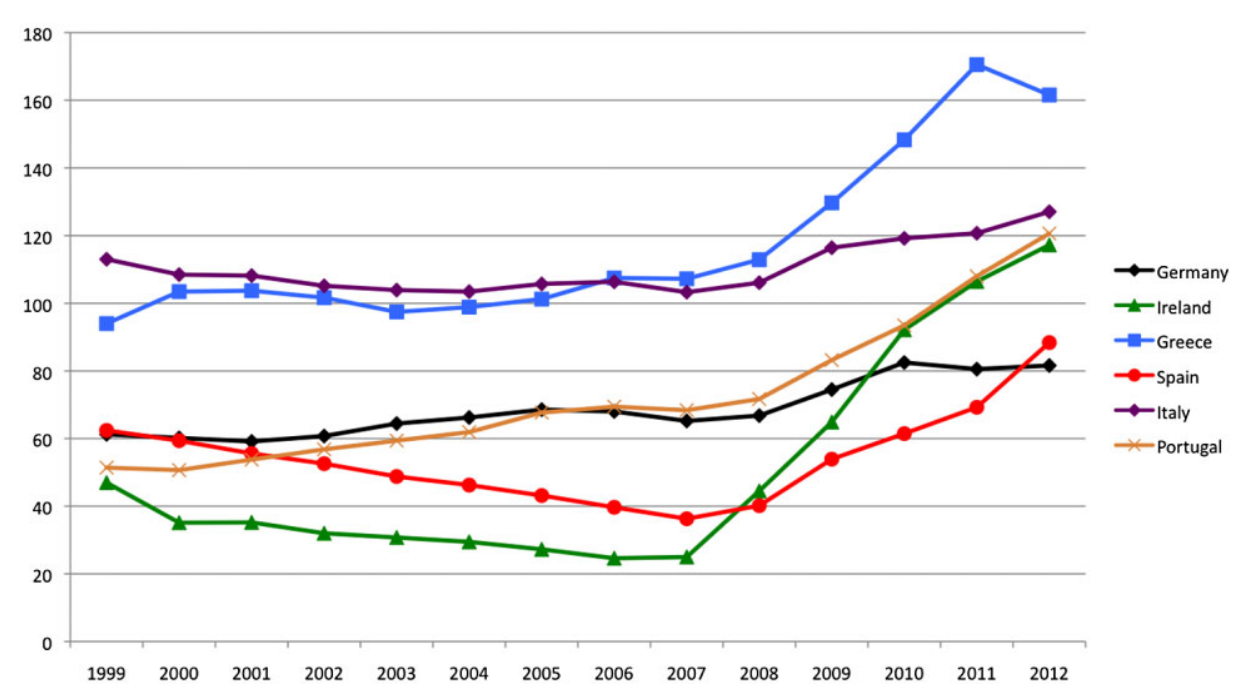

Source: AMECO

representations of the two key fiscal developments in the run-up to the debt crisis show. Figure 1 presents the evolution of debt-to-GDP ratios for Germany and the GIIPS countries (Greece, Ireland, Italy, Portugal, Spain), Figure 2 displays the development of interest rates for 10-year government bonds. Together, the two panels raise the question of why interest rates on sovereign debt converged on the very low German benchmark level despite the fact that Italy, Portugal, and especially Greece had both higher debt-to-GDP ratios and lower credit ratings than Germany. Other things being equal, these indicators would imply a higher default risk for these countries. ${ }^{15}$ The most straightforward explanation of the convergence of sovereign borrowing costs to the German level is therefore that investors did not consider the no-bail-out clause a credible threat. Moreover, the behaviour of regulators and governments seemed to be informed by the same thinking, as indicated by the rules laid down in the Capital Requirements Directive (CRD), which implemented Basel II for the EU and allowed banks to assign a zero risk weight to 'exposures to Member States' central governments' ${ }^{16}$ It can be concluded that although the legal framework of the EMU made a point of not excluding the scenario of a sovereign default, the actual behaviour of both governments and investors suggests that they did not consider default a realistic possibility.

Again, as in the previous subsection, the second question relates to the existence of concrete contingency plans-over and beyond the no-bail-out clause-for the scenario of a sovereign debt crisis. Traditionally, the market for government debt and its possible disruptions are governed by a complex informal regime that has been shaped by the various interested parties (Lipson 1985; Soederberg 2005). Despite several initiatives to the contrary-notably one for a Sovereign Debt Restructuring Mechanism (Krueger 2002)—there is still no formal mechanism at 
Figure 2: Interest Rate on 10-Year Government Bonds, 1993-2013

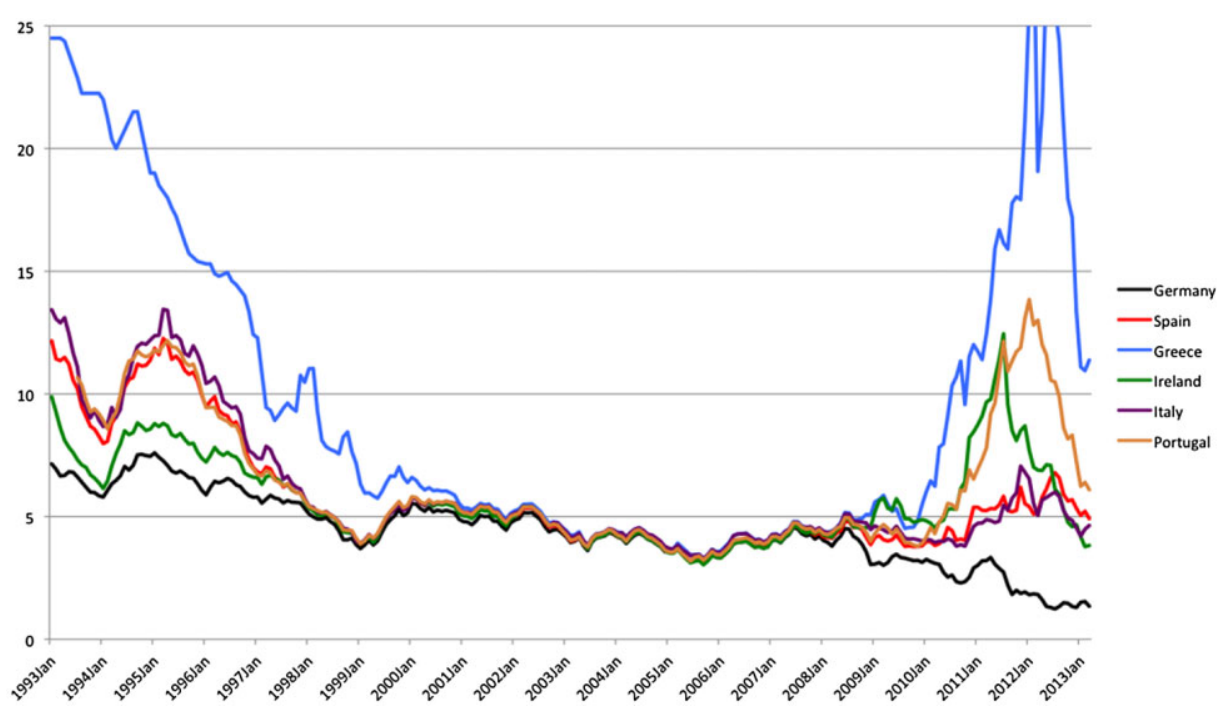

Source: ECB

the international level to deal with sovereign default (Helleiner 2008). The EMU architecture did in no way go beyond this vague international regime-there were virtually no rules in place to deal with a situation in which a member state would face funding difficulties (Buti and Carnot 2012, 905). If at all, the institutional structure was such that in case of solvency problems in one or several countries the likelihood of actual default was higher than in comparable situations in noneurozone countries, given that intra-eurozone bailouts and debt monetisation were ruled out by Art. 125 and Art. 123 TFEU, respectively.

A less well known, yet telling historical detail is that in the early 1990s policymakers assumed that sudden stops of capital inflows and the ensuing balance-ofpayment crises-which in developing countries had often precipitated government solvency problems-would not be an issue within the euro area, because the common currency would eliminate the exchange rate risk. This belief was so strong that the Maastricht treaty expressly excluded euro area members from receiving EU balance-of-payments assistance under Art. 143 of the Treaty, which later prevented the euro area from providing direct financial assistance to Greece (Merler and Pisani-Ferry 2012, 3-4). ${ }^{17}$ The scenario that this thinking had overlooked was the possibility of investors questioning the irreversibility of euro area membership, as happened in the case of Greece, and subsequently also of other countries.

To summarise, the lack of formal rules regarding sovereign insolvency combined with the absence of a bank resolution regime resulted in a situation where the EMU was utterly ill-prepared for the scenario of a widespread sovereign debt crisis. As a consequence, the ECB emerged as the only actor with the legal leeway and the financial resources to make decisive interventions. 


\section{Contingency Acting during the Crisis: ECB to the Rescue!}

In line with existing periodisations (Drudi et al. 2012), the following analysis of the role of the ECB during the emergency phase of the financial crisis distinguishes between a first phase from September 2008 to May 2010, which was primarily a banking crisis, and a second phase from May 2010 to September 2012, when banking and debt crisis were closely intertwined.

\subsection{The ECB as Lender of Last Resort in the First Banking Crisis}

The one truly contingent game changer of the global financial crisis was the decision of the Bush government to let Lehman Brothers fail. The catastrophic fallout from this event made further failures of an even remotely similar scale unthinkable, in the USA as well as in Europe. The prevention of another failure of a too-big-to-fail institution effectively became the overarching goal of crisis management that trumped all other considerations. With this goal in mind, the ECB, in autumn 2008, introduced five 'non-standard measures'18 under the label of 'enhanced credit support' (Trichet 2010b, 12-13; Drudi et al. 2012, 886): First, it provided unlimited short term liquidity to euro area banks at the main refinancing rate. Second, it introduced long term refinancing operations (LTRO), which extended the maximum maturity of central bank liquidity to up to one year. Third, the ECB entered into swap agreements with other central banks to provide liquidity in foreign currencies, especially US dollars. Fourth, the list of securities accepted as collateral in such operations was expanded, that is, collateral standards were lowered. Finally, the ECB launched the Covered Bonds Purchase Programme in May 2009 and acquired covered bonds worth $€ 60$ billion, which it holds until maturity.

In the context of the present argument, the crucial question is whether these measures can be rationalised in the terms of the contingency planning of the pre-crisis policy paradigm. The first point to note is that the Fed's historical mistakes of not acting as LOLR and of letting the money supply collapse in the years following the 1929 crash was not repeated. That said, the more pertinent question is whether the ECB acted in accordance with the classical Bagehot rule, which the previous section identified as a major element of the pre-crisis policy framework for a financial crisis scenario. As mentioned above, the rule states that in a liquidity crisis, the LOLR should lend freely against good collateral at a high interest rate. While the part of 'lend freely' was certainly met, the evaluation of the ECB's compliance with the 'good collateral' and the 'high interest' parts of the Bagehot rule is less straightforward. Regarding the first, what makes for 'good collateral' is difficult to specify, since many securities that are good collateral in normal times are downgraded during a crisis and thus cannot be used as collateral at the central bank anymore. ${ }^{19}$ However, the later decision to accept Greek sovereign bonds regardless of their credit rating supports the conclusion that the ECB's collateral policy constituted a breach of the Bagehot rule (see below). Regarding the 'high interest' prescription, we saw that the notion of moral hazard was at the core of the pre-crisis 
policy paradigm. An interest rate close to pre-crisis market rates was seen as a necessary condition to minimise the ex ante risk of irresponsible behaviour among banks (see the list of quotes in Castiglionesi and Wagner 2012, 202). ${ }^{20}$ During the recent crisis, however, the ECB conducted its LTROs at the main refinancing rate, which has been at the very low level of 1 per cent almost uninterruptedly since May 2009, which is considerably below pre-crisis levels. It can therefore be concluded that the ECB did not lend at 'high' interest rates in its LOLR operations, thereby violating the Bagehot rule (Bordo 2008, 12; Castiglionesi and Wagner 2012, 203). By not validating the ex ante threat of high interest rates and instead providing banks with unlimited funding at virtually no cost, the ECB exacerbated the moral hazard generally associated with LOLR interventions. ${ }^{21}$ As indicated above, however, the reasons why the ECB erred on the side of generosity were the Lehman-shock combined with the absence of a European bank resolution mechanism. The next subsection shows that this absence also compounded the difficulties caused by the sovereign debt crisis.

\subsection{The ECB as Lender of Last Resort in the Twin Crisis}

With the beginning of the 'Greek crisis' in May 2010 and the contagion via the bond markets, which soon triggered a periphery-wide sovereign debt crisis, the euro area entered the second phase of the financial crisis. Even if the information permeated into public consciousness only slowly, this second phase was, right from the start, simultaneously a sovereign debt crisis and a banking crisis. Various mechanisms created a 'vicious link between sovereigns and their banks' (EU Commission $2012 b)$. First, banks had entered the second phase of the crisis in an already-fragile condition, which made them vulnerable to capital losses on their sovereign bond holdings, let alone to an actual default of a euro area member state. Second, peripheral banks' funding costs increased as their credit ratings declined in line with sovereign ratings. This was partly because peripheral banking sectors were the largest creditors of their respective governments, partly because in the absence of a European bank recapitalisation mechanism a bank whose sovereign could not afford a bailout was a bad risk. Finally, due to the fact that government bonds make up for a large share in the collateral used in secured interbank lending, the downgrading of sovereign debtors contributed to an ongoing shortage of 'safe collateral', thus further reducing banks' access to short-term funding (Singh 2011; Singh and Stella 2012).

In the context of the highly integrated European financial market, in which holdings of peripheral sovereign debt were spread across the euro area, even relatively small states, such as Greece, had become too big to fail. Thus, the main reason why the 'troika' of EU, IMF, and ECB went to such great lengths to delay even a partial restructuring of Greek sovereign debt was to give euro area banks time to write off their Greek debt holdings and consolidate their balance sheets. It was thus the lack of a bank resolution authority as well as of a sovereign insolvency mechanism that compounded the consequences of the first phase of the crisis and made the costs of a sovereign default in the euro area prohibitive. The first finding regarding the adherence to the pre-crisis policy paradigm is therefore that the possibility of a sovereign default, which the Maastricht Treaty was so careful not to rule out, had to be ruled out. 
That said the troika supported the default candidates in different ways, not all of which involved the ECB. The primary challenge was to provide Greece-and subsequently Ireland and Portugal—with financing at interest rates that were lower than the prohibitively high market rates. Apart from attempts to bully domestic banks into buying the government's debt, ${ }^{22}$ the first two alternative refinancing options were provided by the rescue packages of the EU and the IMF in the case of Greece, and the newly established European Financial Stability Facility (EFSF) in the cases of Ireland and Portugal. ${ }^{23}$ Here, the euro area member states together with the IMF effectively acted as a 'fiscal lender of last resort'. Designing the rescue packages as loans served to circumvent the no-bail-out clause of Art. 125 TFEU.

In addition to these 'fiscal LOLR' measures, the ECB returned to its post-Lehman activist LOLR role, only this time in support of both banks and governments. Three main decisions were taken in May 2010. First, in order to 'address severe tensions in financial markets' the ECB conducted another unlimited 6-months LTRO at the main refinancing rate (ECB $2010 b)$. Second, for this as well as subsequent LTROs, the ECB suspended the minimum credit rating requirement for Greek bonds, which could now be used as collateral in all transactions with the Eurosystem regardless of their credit rating (ECB 2010a). Third, in what turned out to be its most controversial decision, the ECB launched its Securities Markets Programme (SMP) through which it bought sovereign bonds and other securities in the secondary markets. ${ }^{24}$ The decision was framed by the ECB as a non-standard monetary policy measure to address 'the malfunctioning of securities markets and restore an appropriate monetary policy transmission mechanism' (ECB 2010b).

Moreover, on top of these 'visible' measures, the ECB-or rather, the Eurosystemalso supported the GIIPS countries in a more opaque, albeit perfectly legal, way. As these countries experienced what was essentially a sudden stop of private capital inflows (Merler and Pisani-Ferry 2012) — the scenario that had been deemed impossible by the authors of the Maastricht Treaty-their trade deficits were increasingly financed through TARGET2, the electronic payment and settlement system operated by the Eurosystem. As banks in the GIIPS countries substituted central bank liquidity for private funding from the interbank market, the national central banks of surplus countries accumulated TARGET2 claims on these countries' central banks. In the case of the German Bundesbank, these claims reached $€ 700$ billion in 2012 (De Grauwe and Ji 2012, 2). Notwithstanding the debate about whether the imbalances financed trade deficits (Sinn and Wollmershäuser 2012) or were caused by speculative capital movements (De Grauwe and Ji 2012), the automatic build-up of the TARGET2 imbalances contributed to preventing a painful sudden stop scenario in the euro area periphery.

Over the course of 2011 it became clear that Greece was insolvent, and that the best case scenario would be an orderly debt restructuring in which private creditors would have to accept significant losses. As negotiations closed in on a deal towards the end of the year, the ECB relaunched its Covered Bond Purchase Programme (ECB 2011b) and conducted two further 1-year LTROs in October and December (ECB 201 la). Finally, in December, besides reducing the rating threshold for certain asset-backed securities, the ECB took the radical step of offering banks unlimited funds for a three-year period at the main refinancing rate, which it reduced to 1 per 
cent on the day of the announcement (ECB 2011c). In the two LTROs in December 2011 and February 2012, financial institutions took out $€ 1$ trillion in loans from the ECB.

One way to measure the aggregate impact of these various liquidity provisions is to look at the share of total bank assets financed by ECB liquidity. For the banking sectors of Ireland, Portugal, and Spain this share was roughly 10 per cent at the end of September 2012, while the number for Greece was 30 per cent (Van Rixtel and Gasperini 2012, 21-22). However, although the two 3-year LTROs alleviated worries about funding issues in the banking sector and sparked two stock market rallies, they did not achieve the unstated goal of lowering interest rates on peripheral sovereign debt. Therefore, on 6 September, the ECB announced that if required it stood ready to conduct Outright Monetary Transactions (OMT) in secondary markets for government bonds in order to keep interest rate spreads within certain (unreleased) limits (Draghi 2012). In comparison with its predecessor, SMP, two crucial novelties of OMT stand out. First, there is no upper ceiling to bond purchases, OMT is thus theoretically unlimited. Second, OMT are conditional upon countries formally asking the Troika of EU, ECB, and IMF for financial support and, subsequently, complying with the conditions imposed by the Troika (ECB 2012). Although at the point of writing (March 2013) OMT has yet to be tested, its announcement in August 2012 is widely credited for effectively having ended the emergency phase of the euro area crisis (Financial Times, 14 January 2013) and has earned Mario Draghi the 'Financial Times Person of the Year' award (Financial Times, 13 December 2012).

\section{Concluding Remarks: Making Sense of Some Recent Developments}

The comparison conducted above between pre-crisis contingency planning and in-crisis contingency acting has shown that the dominant role of the ECB resulted from two major inconsistencies in the pre-crisis policy paradigm. First, the combination of a 'benign neglect and mopping up after' approach to financial bubbles with a lack of institutional mechanisms to actually 'mop up after', namely the absence of a comprehensive framework that would have coordinated bank supervision, the LOLR function, and bank resolution at the European level. The second inconsistency was the combination of the no-bail-out and the no-debtmonetisation clauses with a lack of institutional mechanisms to deal with an actual sovereign default within the euro area.

These inconsistencies produced two consequences. The first was that the central crisis-related elements of the pre-crisis policy paradigm had to be abandoned the moment the crisis began-too big to fail banks had to be rescued at any cost, low interest rates on central bank liquidity exacerbated moral hazard, and the no-bailout clause proved meaningless as states also were too big to fail. The second consequence was that this lack of preparedness left a void that only the ECB could fill. True, policy-makers did act as bricoleurs who made use of the tools that were at hand-yet as it turned out, during the emergency phase of the crisis the ECB was virtually the only tool at hand. Crucially, this was the outcome of an ideational dynamic only in the negative sense that there was a void left by the old paradigm. 
It should not be attributed to positive ideational dynamics related to either the old or any putative new policy paradigm. Instead, ECB supremacy during the crisis should be seen as a 'default outcome' that results from the absence of alternative provisions. In a systemic financial crisis, 'he who pays the piper calls the tune' (Goodhart and Schoenmaker 1995, 544). In the absence of institutional alternatives the piper is paid by the central bank, which in a crisis has the deepest pockets by virtue of the fact that it controls the supply of high-powered money.

On the basis of these insights, the remainder of this conclusion offers some tentative reflections on the current prospects for the macroeconomic policy paradigm of the euro area as it relates to the future role of the ECB. As argued above, it is crucial for such a discussion to distinguish between normal and non-normal times. In general, recent developments in financial stability and monetary policy suggest that the euro area is bound to become even more 'ECB-centric' than it was before the crisis (Dyson 2000).

With regard to non-normal times, major changes are currently underway. Most importantly, the Commission has published a proposal for a Single Supervisory Mechanism (SSM) that will confer the task of bank supervision upon the ECB (EU Commission 2012a). ${ }^{25}$ Although supervision is a task also for normal times, the policy-makers who so hastily pushed through the SSM were mainly thinking about non-normal times. Their reasoning was twofold. First, as pointed out by president Barroso, the ultimate aim of the SSM is 'to break the vicious link between sovereigns and their banks' (EU Commission 2012b). The SSM serves this purpose because member state governments had previously declared it a condition for the European Stability Mechanism (ESM, operative since October 2012) to be allowed to recapitalise banks directly (EU Commission 2012b). Second, the reason for concentrating these powers at the ECB-rather than at the European Banking Authority (EBA) or an entirely new regulatory body-is that a central bank that acts as LOLR to banks without formal powers to discipline them, or even without direct access to supervisory information, is in no position to adequately address the moral hazard problems that arise in connection with the LOLR function. Indeed, the ECB's experience of lacking formal powers to impose conditions on banks that received central bank support explains its willingness to assume, and the Commission's eagerness to endow the ECB with these additional responsibilities (Wyplosz 2012 , 12). In other words, while the first of these reasons is related to fiscal considerations (recapitalisation of banks through the ESM), the second reason is related to monetary considerations (provision of liquidity to banks by the ECB). Compared to pre-crisis contingency planning, this thinking represents a major ideational shift, in the sense that the plans for the SSM are based on the recognition that in non-normal times financial stability, fiscal, and monetary policy become inextricably intertwined. Whether this recognition, and the fact that it implies a de-facto politicisation of the role of the ECB, will lead to a loss of formal central bank independence, remains to be seen.

As for the role of the ECB in normal times-monetary policy strictu sensu-there are signs of an ideational change with regard to the role asset prices should play in its reaction function. Here, the strategy of 'benign neglect' has been losing ground to the 'leaning against the wind' approach, both at the ECB and at other central banks 
(Posen 2009; Trichet 2009; Bernanke 2010). However, apart from this 'benign' adjustment, the underlying inflation targeting framework of the ECB remains intact. Considering the significant changes and radical proposals made elsewherethe Fed has recently adopted a (temporary) employment target while the new governor of the Bank of England, Mark Carney, has been talking about a nominal GDP target-this is a non-trivial finding. Again, the point of this article is that at least part of the explanation is to be found in the nexus between crisis preparedness and crisis management. Thus, the dominant role into which the ECB was pushed by the lack of preparedness of the EMU as a whole has strengthened its political position vis-à-vis other actors in a way that has increased its capacity for 'paradigm maintenance' (Wade 1996). This illustrates the point that the relationship between crisis preparedness and paradigm resilience is non-linear and depends on contingent events and developments that occur during a critical juncture. Not unlike Germany, whose fiscal strength has made it the quasi-hegemon among member states, the ECB's monetary resources have propelled it into a hegemonic position within the institutional architecture of the euro area. Therefore, if a paradigm shift in monetary policy remains elusive in the euro area, this will not only be because of a lack of alternative ideas, but also because the crisis has endowed the ECB with the power to defend the existing paradigm if it wishes to do so.

\section{About the Author}

Benjamin Braun, Postdoctoral Fellow, Max Planck Institute for the Study of Societies, Paulstr. 3, 50676 Cologne, Germany, email: b.braun@mpifg.de

\section{Notes}

I would like to thank the organisers (Andrew Baker and Geoffrey Underhill) and participants of the ECPR Joint Sessions workshop on 'Economic Ideas and the Political Construction of Financial Crisis and Reform' in Antwerp, April 10-15, 2012, for their support and constructive criticism. Subsequent versions of this article were presented at the CRESC Annual Conference 2012 in Manchester and the ISA Annual Convention 2013 in San Francisco. The article benefited from the encouragement and feedback of my academic supervisors, Amandine Crespy and Matthew Watson, as well as from the excellent comments made by two anonymous reviewers.

1. In light of the extraordinary expansion of its responsibilities the experience of the ECB during the recent financial crisis falls squarely under this definition. Note that the final outcome of change is not required for a situation to qualify as a critical juncture (Capoccia and Kelemen 2007, 352).

2. Although historical institutionalism has never ruled out that ideas may play a role in processes of institutional change (Hall and Taylor 1996, 942), the research programme in IPE inspired by Hall's (1993) article on policy paradigms has evolved into a separate body of literature that can be described as discursive institutionalism (Schmidt 2008).

3. It should be noted that this article uses a rather narrow concept of 'crisis' - at least when measured against the neo-Marxist view, according to which the crisis is located 'not at the level of events but rather at the superordinate level of mechanisms that generate "events" ' (Offe 1976, 32). Here, 'crisis' consists in the inability of the system to provide the resources for its own reproduction, and is therefore permanent. From this perspective, the period of 2008-12 is simply the final episode of a crisis that has been unfolding ever since the neoliberal revolutions of the Reagan and Thatcher era (for an excellent analysis along such lines see Krippner 2011). However, in order to save the concept of 'crisis' for the extraordinary period of 2008-12, this article follows Colin Hay's (who in turn is quoting Koselleck) reminder that etymologically 'crisis refers to a moment of decisive intervention' (Hay 1999, 323; also see Widmaier et al. 2007).

4. The Cyprus episode, which occurred in March 2013, cannot be said to have posed a systemic threat to the financial system of the euro area. It therefore did not extend the emergency phase beyond July 2012 . 
5. Examples are the Single Supervisory Mechanism, the financial transaction tax, and proposals of the Liikanen Report for a Glass-Steagall-type reform of the banking sector. However, in the area of fiscal policy significant reforms were introduced as early as 2010 (the European Semester).

6. For similar arguments more specifically related to economic crises, see Keeler (1993) and Hay (1999, 339).

7. For a related discussion, albeit in a slightly different theoretical context, of financial crisis preparedness and resilience, see Thompson (2010).

8. For recent ECB research reinforcing the distinction between 'good' and 'bad times', see Fahr et al. (2011) and Lenza et al. (2010).

9. Three arguments justified this 'benign neglect' approach towards asset price inflation and, by implication, financial stability. First, price stability and financial stability were considered complimentary goals, so that controlling the rate of (consumer price) inflation was the best contribution the central bank could make towards financial stability (Bean et al. 2010, 5). Second, although asset price movements influence real economic activity through the 'balance sheet channel', performance of monetary policy cannot be improved by incorporating asset prices into the reaction function of the central bank (Bernanke and Gertler 1999 and 2001). Finally, the efficient market hypothesis suggests that asset price targeting actually is impossible, for if asset prices reflect all available information, the central bank has no informational advantage over market participants. It cannot, therefore, distinguish between 'rational' and 'irrational' bubbles with any certainty.

10. Whether ambiguity was constructive or destructive, there was enough of it to persist right up until 2006, when an IMF working paper explored the question of how the LOLR-function 'might ... materialize during a systemic financial disturbance affecting more than one EU member state' (Schinasi and Teixeira 2006, 3).

11. Indeed, in 2002, at a conference at the occasion of Friedman's 90th birthday, Ben Bernanke ended his speech by addressing Friedman and Schwartz directly: 'Regarding the Great Depression. You're right, we did it. We're very sorry. But thanks to you, we won't do it again' (Bernanke 2002).

12. An explicit reference to Bernanke's research and to the historical awareness of ECB policy-makers can be found in Trichet (2010a). For a detailed analysis for the relationship between Friedman's views and the actions of the Fed in the USA, see Nelson (2011).

13. The classic contributions are Mundell (1961) and Kenen (1969). For a textbook exposition, see De Grauwe (2009, 222-224).

14. In effect, these articles contain two separate no-bail-out clauses. Art. 123 TFEU prevents the ECB and the national central banks from purchasing sovereign debt instruments directly from national governments. Art. 125 excludes the possibility of the EU, the member states, or the ECB paying for or assuming the liabilities of other member states.

15. Under the condition that higher debt burdens are not entirely offset by better growth prospects.

16. While Basel I assigned a zero risk weight for all sovereign debt issued by OECD countries, Basel II used a rating-based approach, according to which the zero risk weight was limited to sovereign bonds with a rating of AA- or higher (Nouy 2012,96). Significantly, prior to the onset of the sovereign debt crisis in 2010, only Greece fell below this threshold (Hannoun 2011, 4, graph 5). More importantly, however, the CRD assigned an across-the-board zero risk weight for all 'exposures to Member States' central governments ... denominated and funded in the domestic currency of that central government' (2006/48/EC, Annex VI, part 1, paragraph 4). This rule was more permissive than what Basel II would have prescribed in that it did not confine the zero risk weight to the standardised approach (used by smaller banks), 'but permit a generalised zero risk weight' for all banks (Hannoun $2011,13)$.

17. I would like to thank André Broome for bringing this point to my attention.

18. The term 'non-standard measures' covers all actions by the ECB that go beyond the setting of the short-term interest rate for monetary policy purposes; for a detailed categorisation, see Lenza et al. $(2010,299)$. For the ECB's own understanding of the nature of non-standard measures and their relationship to standard measures, see Trichet (2010a).

19. The concrete measures relating to the temporary easing of quality standards required for collateral to be eligible in refinancing operations with the ECB (as well as in private repo transactions) are listed in Cheun et al. $(2009,25)$.

20. The interpretation of the phrase 'at a high interest rate' as a recommendation to lend at a 'punitive' rate has been identified as a 'myth' (Goodhart 1999, 341). Instead, the interest rate that Bagehot had in mind was the market rate that prevailed prior to the crisis-and at which distressed banks are unlikely to obtain funding during the crisis.

21. The same point applies to the lending behaviour of the Fed, see Humphrey (2013). 
22. The hypothesis that the Greek government did indeed recur to such 'moral suasion' is supported by the observation that in March 2010 the share of Greek debt in the sovereign debt portfolios of Greek banks amounted to over 95 per cent (Bolton and Jeanne 2011, 15).

23. The first rescue package for Greece was decided in May 2010 by the EU, the ECB, and the IMF. Of the total amount of $€ 110$ billion, the IMF contributed $€ 30$ billion, while the remaining $€ 80$ billion came as bilateral loans from the member states. The European share in the second rescue package of the same magnitude was channelled through the newly established EFSF, whose loans are financed through the emission of bonds for which EMU members are liable in proportion to their relative share in the capital of the ECB.

24. At the end of 2012 the nominal value of accumulated purchases under the now terminated SMP amounted to $€ 218$ billion. The precise composition of the ECB's securities portfolio under the SMP was only made public in February 2013. Italian bonds accounted for almost half of the total nominal value (€102.8 billion), the share of Greek bonds was $€ 33.9$ billion (ECB 2013).

25. Note that in the initial version the SSM will not include a Single Resolution Mechanism (SRM). However, the introduction of the SRM remains a priority of the Commission.

\section{Bibliography}

Aglietta, M. (1999) 'A lender of last resort for Europe', CEPII Working Paper no. 99-12, Centre d'Etudes Prospectives et d'Informations Internationales, Paris.

Bagehot, W. (1873) Lombard Street: A Description of the Money Market (London: Henry S. King and Co.).

Baker, A. (forthcoming) 'Varieties of financial crisis, varieties of ideational change: How and why financial regulation and macroeconomic policy differ', under review at New Political Economy.

BCBS (2010) 'Report and recommendations of the Cross-border Bank Resolution Group', Basel Committee on Banking Supervision.

Bean, C. R. et al. (2010) 'Monetary policy after the fall'. Paper presented at the Federal Reserve Bank of Kansas City Annual Conference in Jackson Hole, Wyoming, 28 August 2010.

Bernanke, B. S. (2000) Essays on the Great Depression (Princeton, NJ: Princeton University Press).

Bernanke, B. S. (2002) 'Remarks by Governor Ben S. Bernanke'. Speech at the Conference to honor Milton Friedman, University of Chicago, 8 November 2002.

Bernanke, B. S. and Gertler, M. (1999) 'Monetary policy and asset price volatility', Economic Review of the Federal Reserve Bank of Kansas City, 84:4, 17-51.

Bernanke, B. S. and Gertler, M. (2001) 'Should central banks respond to movements in asset prices?', The American Economic Review, 91:2, 253-257.

Bernanke, B. S. (2010) 'Monetary policy and the housing bubble'. Speech given at the Annual Meeting of the American Economic Association.

Best, J. (2005) The Limits of Transparency: Ambiguity and the History of International Finance (Ithaca, NY: Cornell University Press).

Best, J. (2008) 'Ambiguity, uncertainty, and risk: Rethinking indeterminacy', International Political Sociology, 2, 355-374.

Best, J. (2012) 'Bureaucratic ambiguity', Economy and Society, 41:1, 84-106.

Blyth, M. (2002) Great Transformations. Economic Ideas and Institutional Change in the Twentieth Century (Cambridge: Cambridge University Press).

Blyth, M. (2013) 'Paradigms and paradox: The politics of economic ideas in two moments of crisis', Governance, 26:2, 197-215.

Bolton, P. and Jeanne, O. (2011) 'Sovereign default risk and bank fragility in financially integrated economies', NBER Working Paper no. 16899.

Bordo, M. D. (2008) 'An historical perspective on the crisis of 2007-2008', NBER Working Paper no. 14569.

Borensztein, E. and Panizza, U. (2008) 'The costs of sovereign default', IMF Working Paper 08/238.

Buiter, W. (1999) 'Alice in Euroland', Journal of Common Market Studies, 37:2, 181-209.

Buti, M. and Carnot, N. (2012) 'The EMU debt crisis: Early lessons and reforms', Journal of Common Market Studies, 50: 899-911.

Capoccia, G. and Kelemen, R. D. (2007) 'The study of critical junctures: Theory, narrative, and counterfactuals in historical institutionalism', World Politics, 59:3, 341-369. 
Carstensen, M. B. (2011) 'Paradigm man vs. the bricoleur: Bricolage as an alternative vision of agency in ideational change', European Political Science Review, 3:1, 147-167.

Castiglionesi, F. and Wagner, W. (2012) 'Turning Bagehot on his head: Lending at penalty rates when banks can become insolvent', Journal of Money, Credit and Banking, 44:1, 201-219.

Cheun, S., Köppen-Mertes, I. V. and Weller, B. (2009) 'The collateral frameworks of the Eurosystem, the Federal Reserve System and the Bank of England and the financial market turmoil', ECB Working Paper No. 107.

Chwieroth, J. M. (2010) 'How do crises lead to change? Liberalizing capital controls in the early years of new order Indonesia', World Politics, 62:3, 496-527.

Cihak, M. and Nier, E. (2009) 'The need for special resolution regimes for financial institutions—the case of the European Union', IMF Working Paper 09/200.

Clarida, R. H. (2012) 'What has-and has not-been learned about monetary policy in a low-inflation environment? A review of the 2000s', Journal of Money, Credit and Banking, 44:1, 123-140.

Crouch, C. (2011) The Strange Non-Death of Neo-Liberalism (Cambridge: Polity).

De Grauwe, P. (2009) The Economics of Monetary Union (8th edn.) (Oxford: Oxford University Press).

De Grauwe, P. and Ji, Y. (2012) 'What Germany should fear most is its own fear: An analysis of Target2 and current account imbalances', CEPS Working Document no. 368, Centre for European Policy Studies, Brussels.

Draghi, M. (2012) 'Introductory statement to the press conference on 6 September 2012', Available online at: http://www.ecb.int/press/pressconf/2012/html/is120906.en.html (last accessed 8 September 2012).

Drudi, F., Durré, A. and Mongelli, F. P. (2012) 'The interplay of economic reforms and monetary policy: The case of the eurozone', Journal of Common Market Studies, 50:6, 881-898.

Dyson, K. (2000) The Politics of the Euro-Zone (Oxford: Oxford University Press).

ECB (2010a) 'Press release 3 May 2010-ECB announces change in eligibility of debt instruments issued or guaranteed by the Greek government', Available online at: http://www.ecb.int/press/pr/date/2010/ html/pr100503.en.html (last accessed 1 April 2012).

ECB (2010b) 'Press release 10 May 2010-ECB decides on measures to address severe tensions in financial markets', Available online at: http://www.ecb.int/press/pr/date/2010/html/prl00510.en.html (last accessed 1 April 2012).

ECB (2011a) 'Press release 6 October 2011-ECB announces details of refinancing operations from October 2011 to 10 July 2012', Available online at: http://www.ecb.int/press/pr/date/2011/html/ prl11006_4.en.html (last accessed 1 April 2012).

ECB (2011b) 'Press release 6 October 2011 -ECB announces new covered bond purchase programme', Available online at: http://www.ecb.int/press/pr/date/201 1/html/prl11006_3.en.html (last accessed 1 April 2012).

ECB (2011c) 'Press release, 8 December 2011-ECB announces measures to support bank lending and money market activity', Available online at: http://www.ecb.int $/ \mathrm{press} / \mathrm{pr} / \mathrm{date} / 201 \mathrm{l} / \mathrm{html} /$ prl11208_l.en.html (last accessed 1 April 2012).

ECB (2012) 'Press release 6 September 2012-technical features of outright monetary transactions', Available online at: http://www.ecb.int/press/pr/date/2012/html/pr120906_l.en.html (last accessed 8 September 2012).

ECB (2013) 'Press release 21 February 2013-details on securities holdings acquired under the Securities Markets Programme', Available online at: http://www.ecb.int/press/pr/date/2013/html/prl30221 _l.en.html (last accessed 18 March 2013).

Eichengreen, B. (1993) 'European monetary unification', Journal of Economic Literature, 31:3, 1321-1357.

Eichengreen, B., Obstfeld, M. and Spaventa, L. (1990) 'One money for Europe? Lessons from the US currency union', Economic Policy, 5:10, 117-187.

EU Commission (2012a) 'Proposal for a council regulation conferring specific tasks on the European Central Bank concerning policies relating to the prudential supervision of credit institutions', Available online at: http://ec.europa.eu/internal_market/finances/docs/committees/reform/20120912-com -2012-511_en.pdf (last accessed 16 October 2012).

EU Commission (2012b) 'Press release 12/09/2012-Commission proposes new ECB powers for banking supervision as part of a banking union', Available online at: http://europa.eu/rapid/press-release_IP -12-953_en.htm (last accessed 18 March 2013). 
Fahr, S. et al. (2011) 'A monetary policy strategy in good and bad times: Lessons from the recent past', ECB Working Paper no. 1336.

Finnemore, M. and Sikkink, K. (1998) 'International norm dynamics and political change', International Organization, 52:4, 887-917.

Folkerts-Landau, D. and Garber, P. M. (1992) 'The European Central Bank: A bank or a monetary policy rule', NBER Working Paper no. 4016.

Friedman, M. and Schwartz, A. J. (1963) A Monetary History of the United States, 1867-1960 (Princeton, NJ: Princeton University Press).

Goodhart, C. A. E. (1999) 'Myths about the lender of last resort', International Finance, 2:3, 339-360.

Goodhart, C. A. E. and Schoenmaker, D. (1995) 'Should the functions of monetary policy and banking supervision be separated?', Oxford Economic Papers, 47:4, 539-560.

Greenspan, A. (2002) 'Opening remarks'. Speech delivered at the Federal Reserve Bank of Kansas City symposium on 'Rethinking stabilization policy' in Jackson Hole, Wyoming, 29 August 2002.

Hall, P. A. (1993) 'Policy paradigms, social learning, and the state: The case of economic policymaking in Britain', Comparative Politics, 25:3, 275-296.

Hall, P. A. and Taylor, R. C. R. (1996) 'Political science and the three new institutionalisms', Political studies, 44:5, 936-957.

Hannoun, H. (2011) 'Sovereign risk in bank regulation and supervision: Where do we stand?'. Paper presented at the Financial Stability Institute High-Level Meeting, Abu Dhabi, UAE, 26 October.

Hay, C. (1999) 'Crisis and the structural transformation of the state: Interrogating the process of change', The British Journal of Politics e International Relations, 1:3, 317-344.

Hay, C. (2011) 'Pathology without crisis? The strange demise of the anglo-liberal growth model', Government and Opposition, 46:1, 1-31.

Helleiner, E. (2008) 'The mystery of the missing sovereign debt restructuring mechanism', Contributions to Political Economy, 27:1, 91-113.

Helleiner, E. (2010) 'A Bretton Woods moment? The 2007-2008 crisis and the future of global finance', International Affairs, 86:3, 619-636.

Humphrey, T. M. (2013) 'Arresting financial crises: The Fed versus the classicals', Levy Economics Institute of Bard College Working Paper no. 751.

IMF (1998) International Capital Markets: Developments, Prospects, and Key Policy Issues (Washington DC: International Monetary Fund).

Issing, O. (2009) 'Asset prices and monetary policy', Cato Journal, 29:1, 45-51.

Katzenstein, P. J. and Nelson, S. (2013) 'Worlds in collision: Uncertainty and risk in hard times', in M. Kahler and D. A. Lake (eds), Politics in the New Hard Times: The Great Recession in Comparative Perspective (Ithaca, NY: Cornell University Press), 233-252.

Keeler, J. T. S. (1993) 'Opening the window for reform: Mandates, crises, and extraordinary policymaking', Comparative Political Studies, 25:4, 433-486.

Kenen, P. B. (1969) 'The theory of optimum currency areas: An eclectic view', in R. A. Mundell and A. K. Swoboda (eds), Monetary Problems of the International Economy (Chicago, IL: Chicago University Press), 41-60.

Keynes, J. M. (1937) 'The general theory of employment', The Quarterly Journal of Economics, 51:2, 209-223.

Kindleberger, C. P. (1978) Manias, Panics, and Crashes: A History of Financial Crises (New York: John Wiley \& Sons).

Krippner, G. R. (2011) Capitalizing on Crisis. The Political Origins of the Rise of Finance (Cambridge, MA: Harvard University Press).

Krueger, A. O. (2002) A New Approach to Sovereign Debt Restructuring (Washington DC: International Monetary Fund).

Kuhn, T. (1962) The Structure of Scientific Revolutions (Chicago, IL: Chicago University Press).

Lenza, M., Pill, H. and Reichlin, L. (2010) 'Monetary policy in exceptional times', Economic Policy, 25:62, $295-339$.

Lipson, C. (1985) 'Bankers' dilemmas: Private cooperation in rescheduling sovereign debts', World Politics, $38: 1,200-225$. 
Mahoney, J. (2001) The Legacies of Liberalism: Path Dependence and Political Regimes in Central America (Baltimore, MD: Johns Hopkins University Press).

Mandelkern, R. and Shalev, M. (2010) 'Power and the ascendance of new economic policy ideas: Lessons from the 1980s crisis in Israel', World Politics, 62:3, 459-495.

Merler, S. and Pisani-Ferry, J. (2012) 'Sudden stops in the Euro area', Bruegel Policy Contribution 2012/06.

Mundell, R. A. (1961) 'A theory of optimum currency areas', The American Economic Review, 51:4, 657-665.

Nelson, E. (2011) 'Friedman's monetary economics in practice', FEDS Working Paper 2011-26, Federal Reserve Board.

Nouy, D. (2012) 'Is sovereign risk properly addressed by financial regulation?', Banque de France Financial Stability Review, 16:95-106.

Offe, C. (1976) 'Crisis of crisis management: Elements of a political crisis theory', International Journal of Politics, 6:3, 29-67.

Oliver, M. J. and Pemberton, H. (2004) 'Learning and change in 20th-century British economic policy', Governance, 17:3, 415-441.

Padoa-Schioppa, T. (1999) 'EMU and banking supervision', International Finance, 2:2, 295-308.

Pierson, P. (2004) Politics in Time: History, Institutions, and Social Analysis (Princeton, NJ: Princeton University Press).

Pisani-Ferry, J. and Sapir, A. (2010) 'Banking crisis management in the EU: An early assessment', Economic Policy, 25:62, 341-373.

Posen, A. S. (2009) 'Finding the right tool for dealing with asset price booms'. Speech to the MPR Monetary Policy and the Economy Conference, London, 1 December.

Reinhart, C. M. and Rogoff, K. S. (2009) This Time Is Different: Eight Centuries of Financial Folly (Princeton, NJ: Princeton University Press).

Schinasi, G. J. and Teixeira, G. P. (2006) 'The lender of last resort in the European single financial market', IMF Working Paper 06/127.

Schmidt, V. A. (2008) 'Discursive institutionalism: The explanatory power of ideas and discourse', Annual Review of Political Science, 11, 303-326.

Singh, M. (2011) 'Velocity of pledged collateral: Analysis and implications', IMF Working Paper 11/256.

Singh, M. and Stella, P. (2012) 'Money and collateral', IMF Working Paper 12/95.

Sinn, H.-W. and Wollmershäuser, T. (2012) 'Target loans, current account balances and capital flows: The ECB's rescue facility', International Tax and Public Finance, 19:4, 1-41.

Soederberg, S. (2005) 'The transnational debt architecture and emerging markets: The politics of paradoxes and punishment', Third World Quarterly, 26:6, 927-949.

Thompson, G. F. (2010) "Financial globalisation" and the "crisis": A critical assessment and "what is to be done"?', New Political Economy, 15:1, 127-145.

Trichet, J-C. (2009) 'Credible alertness revisited'. Speech at the Jackson Hole symposium on Financial Stability and Macroeconomic Policy, 22 August.

Trichet, J-C. (2010a) 'Reflections on the nature of monetary policy non-standard measures and finance theory'. Opening address at the ECB Central Banking Conference in Frankfurt, 18 November 2010.

Trichet, J.-C. (2010b) 'State of the union: The financial crisis and the ECB's response between 2007 and 2009', Journal of Common Market Studies, 48:Annual Review, 7-19.

Van Rixtel, A. and Gasperini, G. (2012) ‘Financial crises and bank funding: Recent experience in the Euro area', BIS Working Paper no. 406.

Wade, R. H. (1996) 'Japan, the World Bank, and the art of paradigm maintenance: The East Asian miracle in political perspective', New Left Review, 217, 3-37.

Widmaier, W., Blyth, M. and Seabrooke, L. (2007) 'Exogenous shocks or endogenous constructions? The meanings of wars and crises', International Studies Quarterly, 51:4, 747-759.

Wyplosz, C. (2012) 'ECB's outright monetary transactions'. Paper prepared for the Policy Department A: Economic and Scientific Policy, requested by the European Parliament's Committee on Economic and Monetary Affairs. 